\title{
KESEHATAN TELINGA SISWA SD KRISTEN EBEN HAEZAR 1 MANADO DAN SD GMIM BITUNG AMURANG KABUPATEN MINAHASA SELATAN
}

\author{
${ }^{1}$ Amelia M. Pardede \\ ${ }^{2}$ Olivia C. P. Pelealu \\ ${ }^{3}$ R. E. C. Tumbel
}

\author{
Kandidat Skripsi Fakultas Kedokteran Universitas Sam Ratulangi Manado \\ Bagian/SMF Telinga Hidung Tenggorok-Bedah Kepala Leher Fakultas Kedokteran \\ Universitas Sam Ratulangi \\ e-mail: ameliapardede@yahoo.com
}

\begin{abstract}
The hearing problem of infants and children can be hard to be detected and can caused the children to have difficulties in learning process. In Indonesia, the increasing of problem needs to have promotive, preventive, curative, and rehabilitative attempts for the people. This research uses descriptive observational method with cross-sectional design to get ear health status from students. In class V-C Eben Haezar 1 Christian Elementary School there are 31 students (17 males, 14 females). Results for students' right ear examination, there are 8 (25,8\%) with cerumen and 23 (74,2\%) normal, meanwhile for the left ear, there are $8(25,8 \%)$ with cerumen, $1(3,2 \%)$ with outer ear wall hyperemic, 1 (3,2\%) with tympanic membrane retraction and 21 (67,7\%) normal. In class V GMIM Bitung Amurang Elementary School there are 18 students (11 males, 7 females). Results for students' right ear examination, there are $8(44,4 \%)$ with cerumen and 10 (55,6\%) normal, meanwhile for the left ear, there are $11(61,1 \%)$ with cerumen and $7(38,9 \%)$ normal. The hearing screening from all students in both schools is normal (100\%). There's a quite big status differentiation of ear health between the two schools. Cerumen cases can be found quite a lot in both schools.
\end{abstract}

Key Words: ear health, hearing screening.

\begin{abstract}
Abstrak: Gangguan pendengaran pada bayi dan anak dapat sulit dideteksi dan mengakibatkan anak sulit menerima pelajaran. Meningkatnya permasalahan ini di Indonesia menyebabkan diperlukan adanya upaya promotif, preventif, kuratif dan rehabilitatif terhadap masyarakat. Penelitian ini menggunakan metode deskriptif observasional secara cross-sectional untuk memperoleh status kesehatan telinga dari siswa. Di kelas V-C SD Kristen Eben Haezar 1 Manado terdapat total 31 siswa (17 laki-laki, 14 perempuan). Hasil untuk telinga kanan, ditemukan 8 siswa (25,8\%) dengan serumen dan $23(74,2 \%)$ normal, sedangkan untuk telinga kiri ditemukan 8 siswa $(25,8 \%)$ dengan serumen, 1 siswa (3,2\%) hiperemis dinding liang telinga luar, 1 siswa (3,2\%) retraksi membran timpani, dan 21 (67,7\%) normal. Di kelas V SD GMIM Bitung Amurang terdapat total 18 siswa (11 laki-laki, 7 perempuan). Hasil untuk telinga kanan, ditemukan 8 siswa (44,4\%) dengan serumen dan 10 (55,6\%) normal, sedangkan untuk telinga kiri ditemukan 11 siswa (61,1\%) dengan serumen dan 7 (38,9\%) normal. Hasil skrining pendengaran dari seluruh siswa di kedua sekolah normal (100\%). Terdapat perbedaan status kesehatan telinga yang cukup besar diantara kedua sekolah. Kejadian serumen cukup banyak ditemukan di kedua sekolah.
\end{abstract}

Kata kunci: kesehatan telinga, skrining pendengaran. 
Telinga adalah salah satu indera manusia yang berfungsi sebagai alat pendengaran dan keseimbangan. Pendengaran pada manusia memegang peranan penting dalam komunikasi sosial serta berfungsi sebagai sistem orientasi untuk menentukan arah dan ruang. ${ }^{1,2}$

Pada tahun 2005, World Health Organization (WHO) memperkirakan terdapat 278 juta orang di seluruh dunia mengalami gangguan pendengaran, 75-140 juta diantaranya terdapat di Asia Tenggara. $^{3}$ Saat ini WHO memperkirakan ada 360 juta $(5,3 \%)$ orang di dunia mengalami gangguan pendengaran, 328 juta (91\%) diantaranya adalah orang dewasa (183 juta laki-laki dan 145 juta perempuan) dan 32 juta (9\%) adalah anakanak. ${ }^{4}$

Gangguan pendengaran pada bayi dan anak dapat sulit dideteksi sehingga tidak segera disadari. Kasus kerusakan pendengaran yang signifikan diperkirakan timbul 1-2 dari 1.000 kelahiran atau terdapat $0,1 \%-0,2 \%$ bayi menderita tuli sejak lahir. Gangguan pendengaran lebih sering terjadi pada anak kecil dan anak kelompok usia belum masuk sekolah. Gangguan pendengaran pada kelompok usia ini biasanya adalah tuli konduksi sekunder yang bersifat sementara dari otitis media, ini terjadi pada 3\%-4\% dari anak-anak. ${ }^{2,3}$

Gangguan pendengaran pada anak dapat disebabkan oleh berbagai macam hal. Berdasarkan data yang didapat Balai Kesehatan Indera Manusia (BKIM) Kota Semarang pada November 2007 yang diperoleh dari anak-anak usia sekolah dasar, dari sebanyak 467 siswa kelas I yang diperiksa telinganya ditemukan persentase kejadian serumen obsturan sebesar 29,55\%, otitis media kronik supuratif (OMKS) 1,28\%, dan sensory neural hearing loss (SNHL) unilateral $0,21 \%{ }^{5}$

Hasil skrining kesehatan telinga dan pendengaran yang dilakukan pada sejumlah siswa sekolah dasar di Desa Sebani, Kabupaten Jombang menunjukkan dari 143 siswa, 50\% diantaranya mengalami penyakit telinga dan gangguan pendengaran dan 93\% diantaranya mengaku tidak pernah memeriksakan kondisi kesehatan telinga. ${ }^{6}$

Gangguan

pendengaran mengakibatkan anak sulit menerima pelajaran, produktivitas menurun, dan biaya hidup tinggi. Informasi dapat diserap $20 \%$ melalui proses mendengar. Hal ini lebih besar dibanding membaca yang hanya menyerap $10 \%$ informasi. ${ }^{3}$ Menurut National Information Center for Children and Youth with Disabilities, anak dengan gangguan pendengaran mengalami kesulitan untuk mempelajari kosakata, tatabahasa, kata perintah, ungkapan, dan aspek lainnya dari komunikasi verbal dibandingkan dengan anak normal. ${ }^{7}$

Meningkatnya permasalahan gangguan pendengaran dan ketulian di Indonesia menyebabkan diperlukan adanya antisipasi dengan melakukan upaya promotif, preventif serta memberikan pelayanan kesehatan indera pendengaran yang optimal sebagai upaya kuratif dan rehabilitatif terhadap masyarakat. ${ }^{3}$

Berdasarkan uraian di atas mengenai tingginya angka kejadian gangguan telinga pada anak sekolah dasar masih cukup tinggi dan untuk menilai apakah ada perbedaan status kesehatan telinga dari siswa sekolah dasar yang tinggal di kota dengan yang tinggal di daerah yang jauh dari pusat kota, maka peneliti tertarik untuk melakukan penelitian ini.

\section{METODE}

Penelitian ini menggunakan metode deskrisptif observasional secara crosssectional. Subjek penelitian yaitu seluruh siswa kelas V-C di SD Kristen Eben Haezar 1 Manado dan seluruh siswa kelas $\mathrm{V}$ di SD GMIM Bitung Amurang Kabupaten Minahasa Selatan. Penelitian ini dilakukan di SD Kristen Eben Haezar 1 Manado pada tanggal 15 November 2013 dan di SD GMIM Bitung Amurang Kabupaten Minahasa Selatan pada tanggal 
18 November 2013. Variabel penelitian

pemeriksaan status kesehatan telinga.

adalah jenis kelamin dan hasil

HASIL

Karakteristik Subjek

Dalam penelitian ini subjek dikategorikan berdasarkan karakteristik jenis kelamin. Di kelas V-C SD Kristen Eben Haezar 1 Manado subjek dengan jenis kelamin laki-laki berjumlah 17 siswa (54,8\%) dan perempuan berjumlah 14 siswa (45,2\%) dengan total 31 siswa. Di kelas V SD GMIM Bitung Amurang Kabupaten Minahasa Selatan subjek dengan jenis kelamin lakilaki berjumlah 11 siswa $(61,1 \%)$ dan perempuan berjumlah 7 siswa $(38,9 \%)$ dengan total 18 siswa. Hal ini dapat dilihat pada Tabel 1.

Tabel 1. Distribusi berdasarkan jenis kelamin

\begin{tabular}{lcccc}
\hline \multirow{2}{*}{ Jenis Kelamin } & \multicolumn{2}{c}{ SD Kr. Eben Haezar 1 Manado } & \multicolumn{2}{c}{ SD GMIM Bitung Amurang } \\
\cline { 2 - 5 } & $\mathbf{n}$ & $\mathbf{\%}$ & $\mathbf{n}$ & $\mathbf{\%}$ \\
\hline Laki-laki & 17 & 54,8 & 11 & 61,1 \\
Perempuan & 14 & 45,2 & 7 & 38,9 \\
Total & 31 & 100 & 18 & 100 \\
\hline
\end{tabular}

\section{Status Kesehatan Telinga}

Penelitian ini dilakukan pada 31 siswa kelas V-C di SD Kristen Eben Haezar 1 Manado dan 18 siswa kelas V di SD GMIM Bitung Amurang Kabupaten Minahasa Selatan. Penelitian ini berupa pemeriksaan pada telinga untuk menilai kesehatan telinga dengan kelainan yang mungkin ditemukan, seperti: serumen, sekret, hiperemis, edema, dan temuan lainnya. Hal ini dapat dilihat pada Tabel 2.

Tabel 2. Distribusi berdasarkan hasil penelitian

\begin{tabular}{lcccccccc}
\hline & \multicolumn{3}{c}{ SD Kr. Eben Haezar 1 Manado } & \multicolumn{3}{c}{ SD GMIM Bitung Amurang } \\
\cline { 2 - 9 } Henelitian & $\begin{array}{c}\text { Telinga } \\
\text { Kanan }\end{array}$ & $\mathbf{\%}$ & $\begin{array}{c}\text { Telinga } \\
\text { Kiri }\end{array}$ & $\mathbf{\%}$ & $\begin{array}{c}\text { Telinga } \\
\text { Kanan }\end{array}$ & $\mathbf{\%}$ & $\begin{array}{c}\text { Telinga } \\
\text { Kiri }\end{array}$ & \% \\
& $\mathbf{n}$ & & $\mathbf{n}$ & & $\mathbf{n}$ & & $\mathbf{n}$ & \\
\hline Serumen & 8 & 25,8 & 8 & 25,8 & 8 & 44,4 & 11 & 61,1 \\
Sekret & 0 & 0 & 0 & 0 & 0 & 0 & 0 & 0 \\
Hiperemis & 0 & 0 & 1 & 3,2 & 0 & 0 & 0 & 0 \\
Edema & 0 & 0 & 0 & 0 & 0 & 0 & 0 & 0 \\
Lain-lain & 0 & 0 & 1 & 3,2 & 0 & 0 & 0 & 0 \\
Normal & 23 & 74,2 & 21 & 67,7 & 10 & 55,6 & 7 & 38,9 \\
Total & 31 & 100 & 31 & 100 & 18 & 100 & 18 & 100 \\
\hline
\end{tabular}

Serumen 
Di kelas V-C SD Kristen Eben Haezar 1 Manado didapatkan 8 siswa (25,8\%) dengan serumen pada telinga kanan dan 8 siswa (25,8\%) dengan serumen pada telinga kiri. Di kelas V SD GMIM Bitung Amurang Kabupaten Minahasa Selatan didapatkan 8 siswa $(44,4 \%)$ dengan serumen pada telinga kanan dan 11 siswa (61,1\%) dengan serumen pada telinga kiri.

\section{Sekret telinga}

Di kelas V-C SD Kristen Eben Haezar 1 Manado dan kelas V SD GMIM Bitung Amurang Kabupaten Minahasa Selatan tidak ditemukan sekret pada liang telinga.

\section{Hiperemis dinding liang telinga luar}

Di kelas V-C SD Kristen Eben Haezar 1 Manado didapatkan 1 siswa (3,2\%) dengan hiperemis dinding liang telinga luar pada telinga kiri. Di kelas V SD GMIM Bitung Amurang Kabupaten Minahasa Selatan tidak ditemukan hiperemis dinding liang telinga luar.

\section{Edema liang telinga luar}

Di kelas V-C di SD Kristen Eben Haezar 1 Manado dan kelas V di SD GMIM Bitung Amurang Kabupaten Minahasa Selatan tidak ditemukan edema pada liang telinga luar.

\section{Temuan lain (perforasi membran timpani, tumor, jamur, dan lainnya)}

Di kelas V-C SD Kristen Eben Haezar 1 Manado didapatkan 1 siswa (3,2\%) dengan retraksi membran timpani pada telinga kiri. Di kelas V SD GMIM Bitung Amurang Kabupaten Minahasa Selatan tidak ditemukan kelainan lainnya.

\section{Normal/tidak ada kelainan}

Di kelas V-C di SD Kristen Eben Haezar 1 Manado didapatkan 23 siswa (74,2\%) dengan hasil normal pada telinga kanan dan 21 siswa $(67,7 \%)$ dengan hasil normal pada telinga kiri. Di kelas V SD GMIM Bitung Amurang Kabupaten Minahasa Selatan didapatkan 10 siswa (55,6\%) dengan hasil normal pada telinga kanan dan 7 siswa (38,9\%) dengan hasil normal pada telinga kiri.

\section{Skrining Pendengaran}

Berdasarkan skrining pendengaran yang dilakukan pada 31 siswa kelas V-C di SD Kristen Eben Haezar 1 Manado dan 18 siswa kelas V di SD GMIM Bitung Amurang Kabupaten Minahasa Selatan didapatkan hasil normal pada kedua telinga (bilateral) dari seluruh siswa (100\%). Hal ini dapat dilihat pada Tabel 3.

Tabel 3. Distribusi berdasarkan hasil skrining pendengaran

\begin{tabular}{|c|c|c|c|c|c|c|c|c|}
\hline \multirow{2}{*}{$\begin{array}{c}\text { Hasil } \\
\text { Skrining } \\
\text { Pendengaran } \\
\end{array}$} & \multicolumn{4}{|c|}{ SD Kr. Eben Haezar 1 Manado } & \multicolumn{4}{|c|}{ SD GMIM Bitung Amurang } \\
\hline & $\begin{array}{c}\text { Telinga } \\
\text { Kanan } \\
\text { n }\end{array}$ & $\begin{array}{c}\text { Telinga } \\
\text { Kiri } \\
\text { n }\end{array}$ & Total & $\%$ & $\begin{array}{c}\text { Telinga } \\
\text { Kanan } \\
\text { n }\end{array}$ & $\begin{array}{c}\text { Telinga } \\
\text { Kiri } \\
\text { n }\end{array}$ & Total & $\%$ \\
\hline Normal & 31 & 31 & 62 & 100 & 18 & 18 & 36 & 100 \\
\hline Terganggu & 0 & 0 & 0 & 0 & 0 & 0 & 0 & 0 \\
\hline Total & 31 & 31 & 62 & 100 & 18 & 18 & 36 & 100 \\
\hline
\end{tabular}


Berdasarkan hasil penelitian dapat dikatakan bahwa terdapat perbedaan status kesehatan telinga yang cukup besar diantara kedua sekolah dasar tersebut. Di SD Kristen Eben Haezar 1 Manado jumlah siswa dengan telinga normal sekitar 3/4 dari total keseluruhan 31 siswa. Di SD GMIM Bitung Amurang Kabupaten Minahasa Selatan jumlah siswa dengan telinga normal hanya sekitar 1/2 dari total keseluruhan 18 siswa.

Berdasarkan hasil penelitian di SD Kristen Eben Haezar 1 Manado ditemukan 8 siswa (25,8\%) dengan serumen pada telinga kanan dan 8 siswa (25,8\%) dengan serumen pada telinga kiri. Di SD GMIM Bitung Amurang Kabupaten Minahasa Selatan ditemukan 8 siswa (44,4\%) dengan serumen pada telinga kanan dan 11 siswa $(61,1 \%)$ dengan serumen pada telinga kiri. Dari data tersebut dapat dilihat bahwa kejadian serumen cukup banyak ditemukan pada siswa sekolah dasar. Hal ini sesuai dengan penelitian sejenis yang sudah pernah dilakukan sebelumnya. ${ }^{5}$ Berdasarkan data ini juga dapat dikatakan bahwa kejadian serumen lebih banyak ditemukan di SD GMIM Bitung Amurang Kabupaten Minahasa Selatan.

Di SD Kristen Eben Haezar 1 Manado ditemukan 1 siswa (3,2\%) dengan hiperemis dinding liang telinga luar pada telinga kiri. Selain itu, di sekolah dasar ini juga ditemukan 1 siswa (3,2\%) dengan retraksi membran timpani pada telinga kiri. Pada penelitian yang dilakukan di SD Kristen Eben Haezar 1 Manado tidak ditemukan sekret dan edema liang telinga, sedangkan di SD GMIM Bitung Amurang Kabupaten Minahasa Selatan tidak ditemukan sekret, edema liang telinga, hiperemis dinding liang telinga luar maupun temuan lainnya.

Jika dibandingkan berdasarkan jumlah kelainan yang ditemukan, lebih banyak variasi kelainan yang ditemukan di SD Kristen Eben Haezar 1 Manado, yaitu: hiperemis dinding liang telinga luar, retraksi membran timpani/temuan lainnya, dan serumen. Di SD GMIM Bitung Amurang Kabupaten Minahasa Selatan hanya ditemukan serumen.

Pada skrining pendengaran yang dilakukan di SD Kristen Eben Haezar 1 Manado maupun di SD GMIM Bitung Amurang didapatkan hasil normal pada kedua telinga (bilateral) dari seluruh siswa yang diperiksa.

Hal-hal yang mungkin mempengaruhi hasil penelitian yang telah diuraikan di atas adalah faktor intelektual dan pola asuh orang tua, faktor kebiasaan anak di lingkungan tempat tinggal dan tempat beraktivitas sehari-hari serta pengetahuan umum mengenai pemeliharaan kesehatan dan kebersihan telinga. Selain itu, hal yang juga berpengaruh adalah kesadaran untuk melakukan pemeriksaan ke dokter bila menyadari adanya gangguan pada telinga.

\section{KESIMPULAN}

Pada penelitian ini dapat disimpulkan bahwa terdapat perbedaan status kesehatan telinga yang cukup besar diantara siswa kelas V-C SD Kristen Eben Haezar 1 Manado dengan siswa kelas V SD GMIM Bitung Amurang Kabupaten Minahasa Selatan. Kejadian serumen cukup banyak ditemukan pada siswa di kedua sekolah. Variasi kelainan lebih banyak ditemukan di SD Kristen Eben Haezar 1 Manado. Hasil skrining pendengaran dari seluruh siswa di kedua sekolah normal pada kedua telinga (bilateral).

\section{SARAN}

Perlu ditingkatkan upaya promosi kesehatan telinga pada siswa sekolah berbagai tingkat. Perlu dilakukan penelitian sejenis secara rutin dan berkala agar dapat mendeteksi secara dini apabila ada kelainan pada telinga anak. Hasil penelitian ini dapat digunakan sebagai bahan masukan untuk penelitian-penelitian selanjutnya mengenai kesehatan telinga, khususnya dikalangan pelajar baik TK, SD, SMP maupun SMA/SMK. 


\section{UCAPAN TERIMA KASIH}

Penulis mengucapkan terima kasih kepada dosen-dosen pembimbing, dosendosen penguji, keluarga, sahabat, dan semua pihak yang baik secara langsung maupun tidak langsung telah menumbuhkan ide/gagasan dalam pemikiran penulis sehingga dapat menyelesaikan artikel ini.

\section{DAFTAR PUSTAKA}

1. Sherwood L. Fisiologi Manusia dari Sel ke Sistem. Ed. 2. Jakarta: EGC, 2001; 176

2. Probst R, Grevers G, Iro H. Basic Otorhinolaryngology. A Step-by-Step Learning Guide. Thieme, 2006; 154,198

3. Depkes RI. Pendengaran Sehat untuk Hidup Bahagia. [homepage on the Internet] c2013. [Cited 2014 Jan 17] Available from: (http://www.depkes.go.id/index.php?vw=2 $\underline{\text { \&id }=2245 \text { ) }}$
4. Depkes RI. Telinga Sehat Pendengaran Baik. [homepage on the Internet] c2011. [Cited 2014 Jan 17] Available from: (http://www.depkes.go.id/index.php?vw=2 \&id=840)

5. Alriyanto CY. Pengaruh Serumen Obturan Terhadap Gangguan Pendengaran (Studi Kasus Pada Siswa Kelas V SD di Kota Semarang). [Skripsi]. Universitas Diponegoro, 2010.

6. Skrining Massal dari Murid SD Hingga Lansia. [homepage on the Internet] Surabaya: FK Universitas Airlangga c2014. [Cited 2014 Jan 17] Available from:

(http://www.fk.unair.ac.id/news/headlinenews/skrining-massal-dari-murid-sdhingga-lansia.pdf)

7. Irmawati D. Hubungan Gangguan Pendengaran Dengan Prestasi Belajar Siswa (Studi Kasus Pada Siswa Kelas V SD di Kota Semarang). [Skripsi]. Universitas Diponegoro, 2010. 